\title{
Fluxo gênico em milho geneticamente modificado com resistência a insetos
}

\author{
Vivian Elias Nascimento(1), Édila Vilela de Resende Von Pinho(1), Renzo Garcia Von Pinho(1), \\ João Cândido de Souza(1) e André Domingos do Nascimento Júnior ${ }^{(1)}$
}

(1)Universidade Federal de Lavras, Caixa Postal 3.037, CEP 37200-000 Lavras, MG. E-mail: vivian_nascimento@hotmail.com, edila@dag.ufla.br,
renzo@dag.ufla.br, cansouza@ufla.br, adrjunior@live.com

Resumo - O objetivo deste trabalho foi estimar o fluxo gênico em milho transgênico com resistência a insetos, em lavouras comerciais. Amostras de grãos foram coletadas em lavouras com milho convencional e transgênico, nos municípios de: Itumirim, Uberlândia, Paracatu e Tupaciguara, MG; Itapetininga e Pedrinhas, SP; e Assaí e Ponta Grossa, PR. As amostras foram coletadas em lavouras de milho convencional, a partir de $5 \mathrm{~m}$ de distância da fonte com o milho transgênico. Foram coletadas dez espigas de plantas individuais por ponto, em quatro repetições, no total de 40 espigas para cada distância amostrada. As análises de fluxo gênico foram realizadas por meio da técnica de reação em cadeia da polimerase (PCR) em tempo real. Em média, $82 \%$ da fecundação cruzada ocorreu nos primeiros $30 \mathrm{~m}$. Em Itapetininga, SP, foram observadas as maiores taxas de fecundação cruzada - acima de $10 \%$ até a distância de $50 \mathrm{~m}$-, porém, inferiores a $1 \%$ na distância de $100 \mathrm{~m}$. O isolamento de 20 m, com dez linhas de bordadura, não é suficiente para garantir taxas de fecundação cruzada inferiores a 1\%.

Termos para indexação: Zea mays, fecundação cruzada, normas de coexistência, PCR em tempo real, transgênicos.

\section{Gene flow on insect-resistant genetically modified maize}

\begin{abstract}
The objective of this work was to estimate the gene flow on insect-resistant transgenic maize in grain production fields. Grain samples were collected in fields containing conventional and transgenic maize in the Brazilian municipalities of: Itumirim, Uberlândia, Paracatu, and Tupaciguara, in the state of Minas Gerais; Itapetininga and Pedrinhas, in the state of São Paulo; and Assaí and Ponta-Grossa, in the state of Paraná. Seed samples were collected in conventional maize crops starting $5 \mathrm{~m}$ away from the transgenic maize source. Ten corn cobs were collected from individual plants per sampling point, with four replicates, totaling 40 corn cobs at each evaluated distance. Gene flow analyses were carried out by real-time polymerase chain reaction (PCR). On average, $82 \%$ of cross-fertilization occurred within the first $30 \mathrm{~m}$. The highest outcrossing rates were observed in Itapetininga, SP, - at rates above $10 \%$ up to a distance of $50 \mathrm{~m}$; however, less than $1 \%$ at $100 \mathrm{~m}$ distance. The $20-\mathrm{m}$ isolation, with ten border lines, is not sufficient to ensure outcrossing rates lower than $1 \%$.
\end{abstract}

Index terms: Zea mays, outcrossing, coexistence norms, real-time PCR, transgenic.

\section{Introdução}

Em 2010, o Brasil ocupou a segunda posição no mundo quanto à área com lavouras geneticamente modificadas (GM), estimada em 25,4 milhões de hectares, dos quais 7,3 milhões foram cultivados com milho transgênico resistente a insetos (James, 2010).

Com o avanço das áreas cultivadas com milho transgênico no Brasil, aumenta a demanda por pesquisas que estimem o fluxo gênico na espécie, com vistas à manutenção da pureza genética em cultivares durante os processos de produção de grãos e sementes. Diversas pesquisas sobre polinização e fluxo gênico em milho já foram realizadas, porém, até o momento, poucas se dedicaram ao milho transgênico nas condições de cultivo do Brasil.

No Canadá, a taxa de dispersão do pólen de milho Bt depende da distância da fonte do pólen, da direção do vento e da coincidência da liberação do pólen com a emissão dos estilos-estigmas das espigas. Conforme Ma et al. (2004), a percentagem de cruzamento é menor do que $1 \%$, dentro de uma distância de $28 \mathrm{~m}$ na direção do vento e de $10 \mathrm{~m}$ na direção oposta; porém, contatou-se que $200 \mathrm{~m}$ é a distância mais apropriada para a separação entre duas cultivares.

O fluxo gênico pode ocorrer em razão da disseminação do pólen, da mistura de sementes ou

Pesq. agropec. bras., Brasília, v.47, n.6, p.784-790, jun. 2012 
da presença de plantas voluntárias, provenientes de cultivos anteriores nas lavouras. Todas essas três fontes podem ser importantes agentes de fluxo gênico; no entanto, o controle do pólen é o que requer mais cuidados (Ramalho \& Silva, 2004).

No Brasil, a Comissão Técnica Nacional de Biossegurança (CTNBio) determinou que, para as liberações comerciais, conforme Resolução Normativa no 4 (Brasil, 2007), a distância entre lavouras GM e convencionais vizinhas deve ser igual ou superior a $100 \mathrm{~m}$ ou, alternativamente, $20 \mathrm{~m}$, desde que acrescida de bordadura com, no mínimo, dez fileiras de plantas de milho convencional de porte e ciclo vegetativo similar ao milho transgênico.

Apesar do estabelecimento da norma de isolamento entre lavouras de milho convencional e transgênico, há discussões a respeito do fato de que o exigido hoje talvez não seja suficiente para assegurar a coexistência entre plantios convencionais e transgênicos, pela ocorrência do fluxo gênico.

O objetivo deste trabalho foi estimar o fluxo gênico em milho transgênico com resistência a insetos, em lavouras comerciais.

\section{Material e Métodos}

O experimento foi realizado em lavouras comerciais, nos seguintes municípios: Itumirim, Uberlândia, Paracatu e Tupaciguara, MG; Itapetininga e Pedrinhas, SP; Assaí e Ponta Grossa, PR; e no Laboratório Central de Sementes, da Universidade Federal de Lavras, Lavras (Ufla), MG, devidamente habilitado, conforme os requisitos da NBR ISO/IEC 17025:2005 (International Organization for Standardization, 2005), e credenciado no Ministério da Agricultura Pecuária e Abastecimento para a execução de tais análises.

Para estimar o fluxo gênico em Itumirim, nas safras de verão de 2008 e verão de 2009, o experimento foi instalado conforme a Figura $1 \mathrm{~A}$. Em um retângulo central, de $1.000 \mathrm{~m}^{2}$, foram cultivadas aproximadamente 6.500 plantas transgênicas, do híbrido DKB390 YieldGard, espaçadas em $0,8 \mathrm{~m}$ entre linhas e, externamente a este, a versão convencional DKB390. $\mathrm{O}$ sincronismo de florescimento entre as cultivares transgênica e convencional foi avaliado no estádio R1, em quatro repetições de 100 plantas. As versões transgênica e convencional dos híbridos utilizados apresentavam ciclos semelhantes. Nas demais áreas, os campos foram instalados em campos comerciais de produtores, conforme Figura $1 \mathrm{~B}$. Na Tabela 1, encontram-se as cultivares utilizadas nas diferentes localidades. O monitoramento visa atender à Resolução Normativa 5, de 12 de março de 2008, da Comissão Técnica Nacional de Biossegurança (Brasil, 2008).

As amostras foram coletadas a partir de $5 \mathrm{~m}$ de distância da fonte transgênica, a cada $10 \mathrm{~m}$ nos primeiros $50 \mathrm{~m}$, e equidistantes de $50 \mathrm{~m}$ a partir dos $50 \mathrm{~m}$. A distância máxima avaliada variou entre locais, em razão da área disponível para amostragem em cada campo analisado.

Foram coletadas dez espigas de plantas individuais por ponto, com quatro repetições espaçadas de $5 \mathrm{~m}$, no total de 40 espigas para cada distância amostrada (Figura 1 B). Após as coletas, as espigas foram transportadas para o Laboratório Central de Sementes
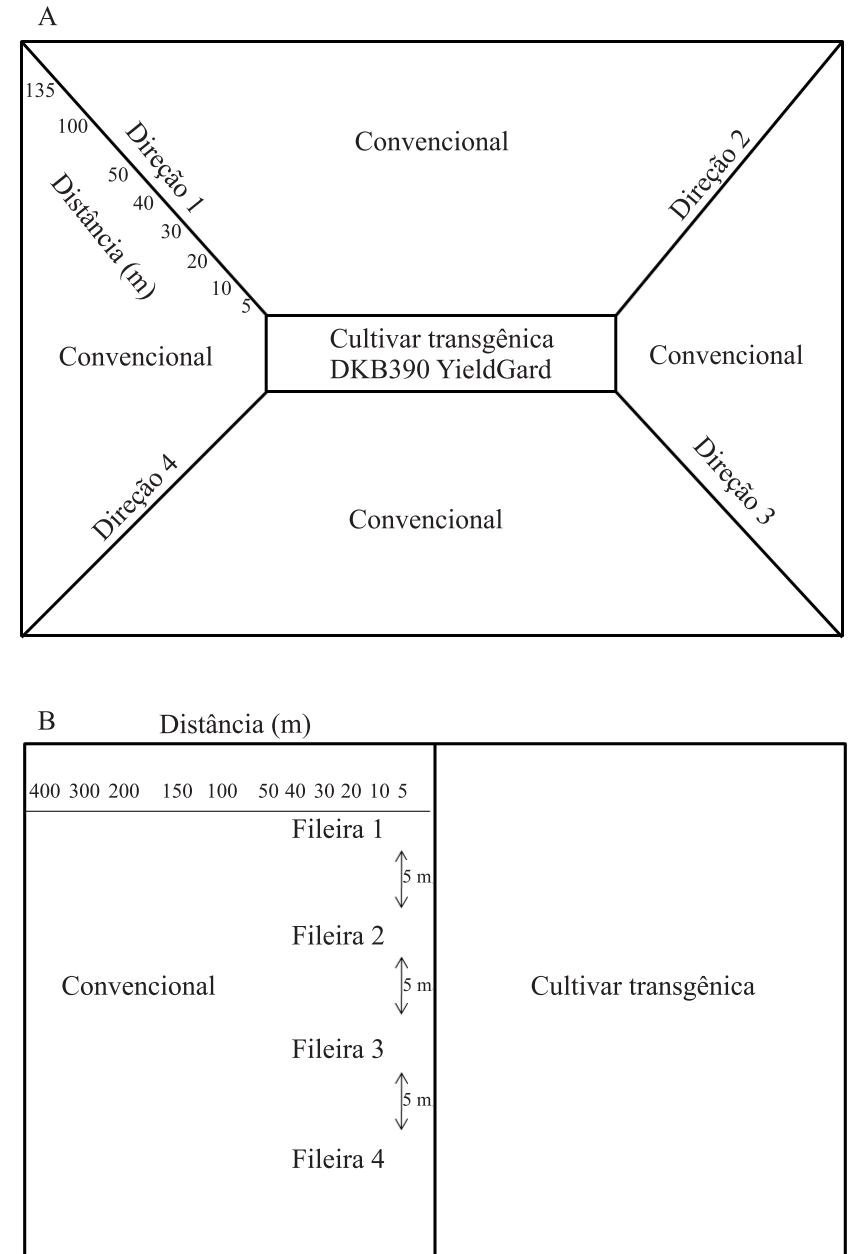

Figura 1. Croquis dos experimentos de identificação de fluxo gênico entre milho transgênico e convencional: A, no Município de Itumirim, MG; B, em áreas comerciais de monitoramento. 
da Ufla, onde foram submetidas à secagem a $35^{\circ} \mathrm{C}$, até os grãos atingirem o teor de água de $14 \%$. Os grãos foram debulhados manualmente, acondicionados em sacos de papel e armazenados em câmara fria regulada a $10 \pm 2{ }^{\circ} \mathrm{C}$ e $75 \pm 5 \%$ UR, até o momento das análises.

Após a homogeneização, foi retirada uma amostra aleatória de aproximadamente 300 sementes. As sementes foram trituradas em liquidificador até obtenção de um pó fino e, em seguida, procedeu-se à extração do DNA para análise e de amostras utilizadas como material de referência com o reagente PrepMan UltraSamplePreparation Reagent(AppliedBiosystems, Foster City, CA, EUA), conforme recomendações do fabricante.

Como material de referência, para a determinação do percentual de OGM nas amostras, foram utilizados os padrões certificados (CRM) ERM-BF412 e BF13a, produzidos pelo Institute for Reference Materials and Measurement (IRMM, www.irmm.jrc.be). Foram utilizadas amostras com $0,1,0,5,1,0,2,0$ e 5,0\% $\left(\mathrm{p} \mathrm{p}^{-1}\right)$ de milho Bt11 e MON810.

As reações de RTq-PCR quantitativo foram efetuadas no equipamento ABI PRISM 7500 Sequence Detection System (Applied Biosystems, Foster City, CA, EUA). As amostras foram amplificadas, por meio do kit de detecção TaqMan GMO Maize 35S Detection Kit (Applied Biosystems, Foster City, CA, EUA), para os alvos CaMV $35 \mathrm{~S}$ (promotor) e zeína (referência endógena). As condições de termociclagem foram: $9 \min$ a $95^{\circ} \mathrm{C}$ e 40 ciclos de $20 \mathrm{~s} \mathrm{a} 95^{\circ} \mathrm{C}, 1 \mathrm{~min}$ a $60^{\circ} \mathrm{C}$ e $30 \mathrm{~s}$ a $72^{\circ} \mathrm{C}$, em volume final de $25 \mu \mathrm{L}$. Todas as amostras foram processadas em triplicata.

Os dados foram processados por meio do programa v.2.0.1, do sistema 7500 de PCR em tempo real (Applied Biosystems, Foster City, CA, EUA), tendo-se utilizado a quantificação absoluta pelo método do $\Delta \mathrm{Ct}$ ("threshold cycle"). Em seguida, os resultados foram

Tabela 1. Relação das cultivares de milho utilizadas nas diferentes localidades.

\begin{tabular}{lcc}
\hline Local & Convencional & Transgênica \\
\hline Itumirim, MG & DKB390 & DKB390Y \\
Uberlândia, MG & Impacto & Maximus TL \\
Paracatu, MG & DKB390 & Maximus TL \\
Tupaciguara, MG & AG7088 & Maximus TL \\
Itapetininga, SP & Maximus & Maximus TL \\
Assaí, PR & Formula & Maximus TL \\
Ponta Grossa, PR & Impacto & Maximus TL \\
Pedrinhas, SP & Impacto & Tork TL \\
\hline
\end{tabular}

exportados para GMO Analysis Macro v1.7.2 (Applied Biosystems, Foster City, CA, EUA), para o cálculo das percentagens de OGM nas amostras analisadas. Foram considerados: $\mathrm{Ct}$ (aumento exponencial do produto de PCR) do gene 35S e controle endógeno (zeína), $\Delta \mathrm{Ct}=\mathrm{Ct}$ (amostra) - $\mathrm{Ct}$ (controle endógeno).

O cálculo da eficiência da PCR em tempo real foi realizado de acordo com o seguinte estimador: Eficiência $=10^{(-1 / \text { inclinação) }}{ }^{-1}$; em que inclinação é representado pelo coeficiente angular (a) no modelo de equação de regressão linear $\mathrm{y}=\mathrm{ax}+\mathrm{b}$.

Segundo os critérios de aceitação do European Network of GMO Laboratories ENGL (2008), a inclinação deve estar entre -3,1 e -3,6; ou seja, eficiência entre 90 e $110 \%$ e $\mathrm{R}^{2} \geq 0,98$.

Os dados de percentagem de fecundação cruzada foram submetidos à análise de variância, com uso do programa Sigma Plot (2006), e as médias foram comparadas pelo teste t, a $5 \%$ de probabilidade.

\section{Resultados e Discussão}

No Município de Itumirim, na safra 2008/2009, a maior taxa de fecundação cruzada (13,32\%), proveniente do milho transgênico DKB390Y, ocorreu à distância de $5 \mathrm{~m}$ na direção 3 (Tabela 2). Nas direções 1 e 2, a taxa de fecundação cruzada foi muito baixa. Presença adventícia superior a 1\% ocorreu somente até a distância de $20 \mathrm{~m}$ da fonte de pólen. A partir de $100 \mathrm{~m}$ da fonte de pólen de plantas transgênicas, não foi observada fecundação cruzada.

Em Tupaciguara, MG, a percentagem de fecundação cruzada, nos $5 \mathrm{~m}$ da fonte de pólen de plantas transgênicas, foi 0,30 (Tabela 3). Nessa área, a cultivar Maximus TL foi cultivada em área inferior em relação ao híbrido convencional AG 7088. Observou-se que, a $50 \mathrm{~m}$ de distância, ocorreu fecundação cruzada de $0,20 \%$, e uma pequena percentagem $(0,04 \%)$ foi verificada aos $400 \mathrm{~m}$. Não houve diferença significativa entre as taxas de fecundação cruzada observadas nas distâncias avaliadas.

Em Itapetininga, SP, em todas as distâncias amostradas até $50 \mathrm{~m}$, a fecundação cruzada foi superior a 10\% (Figura 2). Na distância de $100 \mathrm{~m}$, observou-se presença adventícia inferior a $1 \%(0,5 \%)$. A taxa de fecundação cruzada observada aos $5 \mathrm{~m}$ foi significativamente superior às observadas nas demais distâncias. Entre as distâncias de 20, 30 e 40 m, não ocorreu diferença significativa nos valores de

Pesq. agropec. bras., Brasília, v.47, n.6, p.784-790, jun. 2012 
fecundação cruzada, assim como entre as distâncias 50 e $60 \mathrm{~m}$. Essa alta taxa de fecundação cruzada pode ter ocorrido por diversos fatores, como direção do vento, topografia plana e a utilização de isolinhas, já que,

Tabela 2. Estimativa de percentagem média de fecundação cruzada de milho transgênico DKB390Y, detectada nas diferentes distâncias e direções amostradas, no Município de Itumirim, MG, safras 2008/2009 e 2009/2010 (1).

\begin{tabular}{|c|c|c|c|c|}
\hline \multirow[t]{2}{*}{ Direção } & \multicolumn{2}{|c|}{ Safra 2008/2009 } & \multicolumn{2}{|c|}{ Safra 2009/2010 } \\
\hline & $\begin{array}{l}\text { Fecundação } \\
\text { cruzada (\%) }\end{array}$ & Desvio-padrão ${ }^{(2)}$ & $\begin{array}{l}\text { Fecundação } \\
\text { cruzada (\%) }\end{array}$ & Desvio-padrão ${ }^{(2)}$ \\
\hline & \multicolumn{4}{|c|}{ Distância $5 \mathrm{~m}$} \\
\hline 1 & 0,00 & 0,00 & 1,94 & 0,12 \\
\hline 2 & 0,12 & 0,50 & 0,00 & 0,00 \\
\hline 3 & 13,32 & 0,19 & 0,96 & 0,05 \\
\hline \multirow[t]{2}{*}{4} & 0,06 & 0,01 & 0,20 & 0,47 \\
\hline & \multicolumn{4}{|c|}{ Distância $10 \mathrm{~m}$} \\
\hline 1 & 0,01 & 0,14 & 0,02 & 0,44 \\
\hline 2 & 0,01 & 0,05 & 0,00 & 0,00 \\
\hline 3 & 3,06 & 0,04 & 2,63 & 0,11 \\
\hline \multirow[t]{2}{*}{4} & 0,00 & 0,00 & 0,00 & 0,00 \\
\hline & \multicolumn{4}{|c|}{ Distância $20 \mathrm{~m}$} \\
\hline 1 & 0,06 & 0,13 & 0,03 & 0,11 \\
\hline 2 & 0,00 & 0,05 & 0,00 & 0,00 \\
\hline 3 & 2,76 & 0,32 & 1,67 & 0,43 \\
\hline \multirow[t]{2}{*}{4} & 0,03 & 0,30 & 0,00 & 0,00 \\
\hline & \multicolumn{4}{|c|}{ Distância $30 \mathrm{~m}$} \\
\hline 1 & 0,00 & 0,00 & 0,00 & 0,00 \\
\hline 2 & 0,00 & 0,00 & 0,00 & 0,00 \\
\hline 3 & 0,15 & 0,05 & 0,50 & 0,08 \\
\hline \multirow[t]{2}{*}{$\underline{4}$} & 0,03 & 0,05 & 0,00 & 0,00 \\
\hline & \multicolumn{4}{|c|}{ Distância $40 \mathrm{~m}$} \\
\hline 1 & 0,00 & 0,00 & 0,00 & 0,00 \\
\hline 2 & 0,06 & 0,12 & 0,00 & 0,00 \\
\hline 3 & 0,00 & 0,00 & 0,00 & 0,00 \\
\hline \multirow[t]{2}{*}{4} & 0,24 & 0,20 & 0,00 & 0,00 \\
\hline & \multicolumn{4}{|c|}{ Distância $50 \mathrm{~m}$} \\
\hline 1 & 0,00 & 0,00 & 0,00 & 0,00 \\
\hline 2 & 0,00 & 0,00 & 0,00 & 0,00 \\
\hline 3 & 0,04 & 0,08 & 0,04 & 0,08 \\
\hline \multirow[t]{2}{*}{4} & 0,00 & 0,00 & 0,00 & 0,00 \\
\hline & \multicolumn{4}{|c|}{ Distância $100 \mathrm{~m}$} \\
\hline 1 & 0,00 & 0,00 & 0,00 & 0,00 \\
\hline 2 & 0,00 & 0,00 & 0,00 & 0,00 \\
\hline 3 & 0,00 & 0,00 & 0,00 & 0,00 \\
\hline \multirow[t]{2}{*}{$\underline{4}$} & 0,00 & 0,00 & 0,00 & 0,00 \\
\hline & \multicolumn{4}{|c|}{ Distância $135 \mathrm{~m}$} \\
\hline 1 & 0,00 & 0,00 & 0,00 & 0,00 \\
\hline 2 & 0,00 & 0,00 & 0,00 & 0,00 \\
\hline 3 & 0,00 & 0,00 & 0,00 & 0,00 \\
\hline 4 & 0,00 & 0,00 & 0,00 & 0,00 \\
\hline Média & 0,00 & & 0,00 & \\
\hline
\end{tabular}

${ }^{(1)} \mathrm{R}^{2}$ de 0,99 ; eficiência de reação de $99 \%$. ${ }^{(2)}$ Desvio-padrão aceitável: $\leq 0,5$. nesse campo, os híbridos utilizados foram Maximus e Maximus TL, em que houve o sincronismo de florescimento entre os materiais avaliados.

De acordo com Luna (2001) e Borém \& Ramalho (2002), declividade, direção do vento e sincronismo de florescimento entre os genótipos podem influenciar a incidência de fecundação cruzada. Assim, todos esses fatores devem ser levados em consideração na avaliação do fluxo gênico em milho.

De acordo com a legislação vigente sobre a coexistência entre os sistemas de cultivos (Brasil, 2007), a distância entre lavouras convencional e transgênica deve ser igual ou superior a $100 \mathrm{~m}$, ou, alternativamente, $20 \mathrm{~m}$, desde que acrescida de bordadura com no mínimo dez fileiras de plantas de milho convencional, de porte e ciclo vegetativo similar á cultivar transgênica. Pelos resultados do presente trabalho, os $20 \mathrm{~m}$ com as 10 fileiras de bordadura não seriam suficientes para evitar a fecundação cruzada superior a $1 \%$, uma vez que a fecundação cruzada nessa distância foi de 38,3\% (Figura 2).

Em Pedrinhas, SP, observou-se que a fecundação cruzada foi inferior a $1 \%$, em todas as distâncias avaliadas, sem diferença significativa entre elas (Tabela 3). Nessa área, as plantas de milho transgênico floresceram sete dias antes do milho convencional, o que pode explicar o baixo nível de fecundação cruzada observado. Embora o florescimento das plantas tenhase iniciado sete dias antes das plantas convencionais, um pendão de milho pode liberar pólen por mais de uma semana, e a polinização efetiva pode ocorrer entre 2 e 14 dias; por isso a presença adventícia na

Tabela 3. Estimativa da percentagem cumulativa de fecundação cruzada por pólen a várias distâncias, em nove campos com milho transgênico.

\begin{tabular}{lccccccc}
\hline Campo & \multicolumn{7}{c}{ Distância $(\mathrm{m})$} \\
\cline { 2 - 8 } & 5 & 10 & 20 & 30 & 40 & 50 & 100 \\
\hline Itumirim, MG, 2008/2009 & 65 & 80 & 94 & 95 & 96 & 100 & 100 \\
Tupaciguara, MG & 28 & 40 & 50 & 61 & 65 & 83 & 89 \\
Itapetininga, SP & 23 & 42 & 62 & 83 & 93 & 99 & 100 \\
Pedrinhas, SP & 19 & 44 & 60 & 82 & 90 & 95 & 100 \\
Assaí, PR & 50 & 72 & 81 & 90 & 94 & 97 & 100 \\
Paracatu, MG & 52 & 90 & 93 & 95 & 96 & 97 & 99 \\
Itumirim, MG, 2009/2010 & 40 & 73 & 93 & 99 & 99 & 100 & 100 \\
Uberlândia, MG & 35 & 53 & 53 & 58 & 83 & 100 & 100 \\
Ponta Grossa, PR & 46 & 60 & 70 & 76 & 92 & 99 & 100 \\
\hline Média & 38 & 62 & 73 & 82 & 90 & 97 & 99 \\
\hline
\end{tabular}


área convencional, mesmo não tendo ocorrido total coincidência do florescimento.

Alvim (2008), ao estudar a viabilidade e conservação do grão de pólen, observou que o poder germinativo deste varia com a umidade relativa do ar, com a temperatura e se reduz com a dessecação e com o armazenamento. O pólen pode permanecer viável por até 24 horas, mas sua viabilidade pode ser reduzida em poucas horas quando submetido à baixa umidade e a altas temperaturas (Davide et al., 2009). Em Pedrinhas, SP, o clima é úmido, com variação de temperatura entre 9,2 e $26,1^{\circ} \mathrm{C}$.

Somente nos municípios de Itapetininga, SP, e Itumirim, MG, foram cultivadas a cultivar transgênica e sua versão convencional, e este é um importante fator para a coincidência do florescimento e a ocorrência do fluxo gênico.

Na safra 2009/2010, em Itumirim, MG, fecundação cruzada superior a $1 \%$ ocorreu somente até a distância de $20 \mathrm{~m}$, e superior a $0,5 \%$ foi observada até a distância de $30 \mathrm{~m}$ (Tabela 2). Entre 5 e $10 \mathrm{~m}$, não houve diferença significativa nas taxas de fecundação cruzada. No entanto, o valor observado aos $5 \mathrm{~m}$ foi significativamente superior aos observados nas distâncias acima de $20 \mathrm{~m}$ da área com transgênico. Houve diferença significativa também nas taxas de fecundação cruzada observada entre 30 e $50 \mathrm{~m}$.

Segundo Aragão (2004), a taxa de fecundação cruzada pode ser afetada por vários fatores; entre eles, a

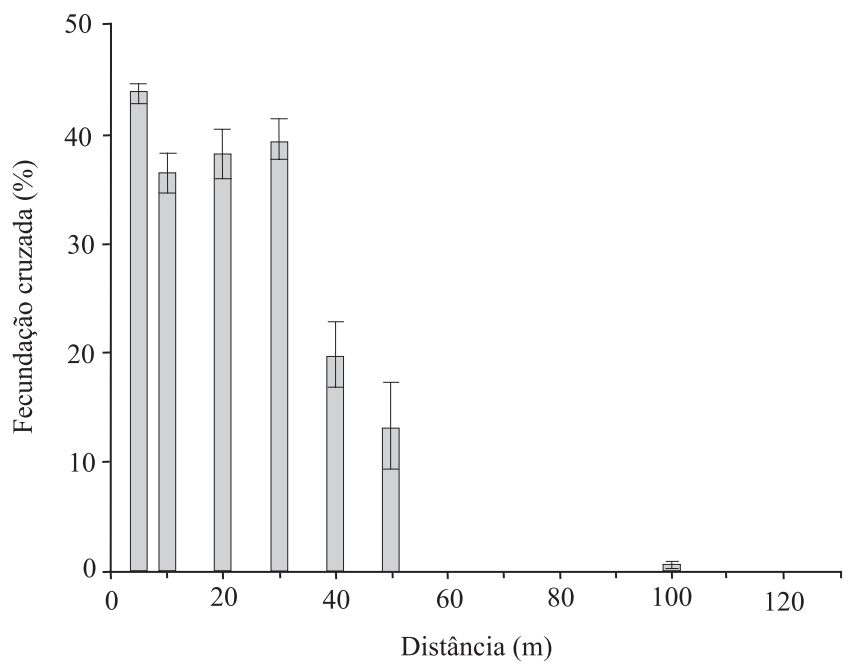

Figura 2. Percentagem média de fecundação cruzada, detectada nas diferentes distâncias, no Município de Itapetininga, SP, safra 2008/2009. densidade e o tamanho da população doadora de pólen. Observa-se que, em Itumirim, MG, onde a área cultivada com transgênicos foi apenas um quadrado central com $1.000 \mathrm{~m}^{2}$, ocorreram menores taxas de fecundação cruzada nas distâncias maiores, em comparação com as áreas comerciais de monitoramento.

Embora o resultado encontrado à distância de $5 \mathrm{~m}$, na safra 2008/2009 em Itumirim, MG, tenha sido bem superior (Tabela 2), de maneira geral, observaram-se resultados semelhantes em ambas as safras, nas demais distâncias. Observa-se também que o fluxo gênico ocorreu, predominantemente, até cerca de $50 \mathrm{~m}$ da fonte.

Os resultados apresentados estão de acordo com os de vários estudos realizados em outros países, em que se observa que a partir dos $5 \mathrm{~m}$ ocorre rápido decréscimo na taxa de fecundação cruzada (Luna et al., 2001; Henry et al., 2003; Ma et al., 2004). Nos EUA, Jemison \& Vayda Junior (2001) estudaram o fluxo gênico de milho resistente a herbicidas e constataram, na distância de $100 \mathrm{~m}$, presença adventícia que variou de 0,7 a $1,4 \%$. No presente trabalho, no entanto, os resultados estão muito próximos aos de outros autores, como Byrne \& Fromherz (2003), com 0,05\% em 183 m.

Considerando-se os resultados observados nas nove áreas avaliadas, $82 \%$ da fecundação cruzada proveniente do milho geneticamente modificado ocorreu nos primeiros $30 \mathrm{~m}$ e, na maioria dos casos, uma pequena percentagem desta variável foi observada aos $100 \mathrm{~m}$ de distância (Tabela 3). Eastham \& Sweet (2002), ao estudar o fluxo gênico em sete campos no Canadá, que continham o gene $\mathrm{Bt}$, observaram que $89 \%$ do pólen foi depositado nos primeiros $5 \mathrm{~m}$. Nas distâncias de 50 e 100 m, os resultados encontrados por estes autores foram semelhantes aos encontrados no presente trabalho.

Outro aspecto refere-se ao isolamento adotado no presente trabalho, em todas as áreas avaliadas. Nos diferentes isolamentos avaliados, havia uma barreira vegetal constituída por plantas de cultivares convencionais que, de alguma forma, restringiam a fecundação cruzada a partir das plantas transgênicas. Assim, levando-se em consideração a Resolução Normativa $\mathrm{n}^{0} 4$ da CTNBio (Brasil, 2007), que estabelece as normas de coexistência, a taxa de fecundação cruzada, aos $20 \mathrm{~m}$ de isolamento, representa um dos sistemas propostos no país. Ao mesmo tempo, também está prevista a possibilidade de 
isolamento à distância de 100 m, sem qualquer barreira vegetal. No entanto, a instalação de experimentos para a avaliação de fecundação cruzada, considerando-se o isolamento sem barreira vegetal, a diferentes distâncias, torna-se muitas vezes inviável. Neste contexto, ao considerar os isolamentos entre 20 e $30 \mathrm{~m}$, na área de Itapetininga, SP, e Itumirim, MG, foi observado o valor de fecundação cruzada superior a $1 \%$, ou seja, essa distância de isolamento não é segura para atender à legislação brasileira de rotulagem de alimentos que apresentam OGM acima de 1\% (Brasil, 2003). Para a exportação de grãos, há a necessidade de se atender aos padrões dos países importadores que, muitas vezes, são inferiores ao padrão do Brasil.

Outro questionamento refere-se à comercialização de grãos isentos de qualquer traço do transgênico, para atender a mercados específicos, ou seja, o limite zero. Neste caso, o padrão tolerado é mais rígido em relação ao adotado para a rotulagem de produtos. No entanto, com o aumento de áreas transgênicas de milho no país, e considerando-se a possibilidade de contaminações genética e varietal nesta espécie, a produção de grãos e sementes sem qualquer traço de transgênico torna-se cada vez mais difícil.

Na prática, observa-se que é difícil evitar que ocorra fluxo gênico entre plantas sexualmente compatíveis, que estejam em áreas próximas e florescendo ao mesmo tempo, principalmente para alógamas, como o milho, polinizadas pelo vento. Embora em muitos casos a transferência gênica em plantios comerciais seja irrelevante, em campos experimentais dos programas de melhoramento e de produção de sementes essas distâncias devem ser consideradas, no sentido de evitar a introgressão não intencional de genes em determinadas linhagens (Aragão, 2004). Observa-se, cada vez mais, a necessidade de estabelecimento de padrões oficiais para a mistura de OGM, em sementes e grãos convencionais de milho, para justificar inclusive a adoção de coexistência.

\section{Conclusões}

1. A $100 \mathrm{~m}$ de isolamento, ocorre fecundação cruzada a taxas inferiores a $1 \%$.

2. O isolamento de $20 \mathrm{~m}$, com dez linhas de bordadura, não é suficiente para garantir taxas de fecundação cruzada inferiores a $1 \%$.

3. Em média, $82 \%$ da fecundação cruzada ocorre nos primeiros $30 \mathrm{~m}$.

\section{Referências}

ALVIM, P.O. Viabilidade e conservação de grãos de pólen de milho. 2008. 59p. Dissertação (Mestrado) - Universidade Federal de Lavras, Lavras.

ARAGÃO, F.J.L. Organismos geneticamente modificados: impacto do fluxo gênico. In: MIR, L. (Org.). Genômica. São Paulo: Atheneu, 2004. p.767-783.

BORÉM, A.; RAMALHO, M.A.P. Escape gênico e impacto ambiental. Biotecnologia, Ciência e Desenvolvimento, v.5, p.44-47, 2002.

BRASIL. Decreto $n^{\circ} 4.680$, de 24 de abril de 2003. Regulamenta o direito à informação, assegurado pela Lei $n^{0} 8.078$, de 11 de setembro de 1990, quanto aos alimentos e ingredientes alimentares destinados ao consumo humano ou animal que contenham ou sejam produzidos a partir de organismos geneticamente modificados, sem prejuízo do cumprimento das demais normas aplicáveis. Diário Oficial [da] República Federativa do Brasil, Poder Executivo, Brasília, 25 abr. 2003.

BRASIL. Ministério da Ciência, Tecnologia e Inovação. Comissão Técnica Nacional de Biossegurança. Resolução normativa $n^{\circ} 05$, de 12 de março de 2008. Dispõe sobre normas para liberação comercial de organismos geneticamente modificados e seus derivados. Diário Oficial [da] República Federativa do Brasil, Poder Executivo, Brasília, 13 mar. 2008. Seção 1, p.6.

BRASIL. Ministério da Ciência, Tecnologia e Inovação. Comissão Técnica Nacional de Biossegurança. Resolução normativa $n^{\circ} 04$, de 16 de agosto de 2007. Dispõe sobre as distâncias mínimas entre cultivos comerciais de milho geneticamente modificado e não geneticamente modificado, visando à coexistência entre os sistemas de produção. Diário Oficial [da] República Federativa do Brasil, Poder Executivo, Brasília, 23 ago. 2007. Seção 1, p.19.

BYRNE, P.F.; FROMHERZ, S. Can GM and non-GM crops coexist? Setting a precedent in Boulder County, Colorado, USA. Food, Agriculture and Environment, v.1, p.258-261, 2003.

DAVIDE, L.M.C.; PEREIRA, R.D.; ABREU, G.B.; SOUZA, J.C. de; VON PINHO, É.V. de R. Viabilidade de pólen de milho em diferentes períodos de armazenamento em baixa temperatura. Revista Brasileira de Milho e Sorgo, v.8, p.199-206, 2009.

EASTHAM, K.; SWEET, J. Genetically modified organisms (GMOs): the significance of gene flow through pollen transfer. Copenhagen: European Environment Agency, 2002. 75p. (EEA, 28).

EUROPEAN NETWORK OF GMO LABORATORIES ENGL. Definition of minimum performance requirements for analytical methods of GMO testing. [S.1.]: Community Reference Laboratory, 2008. 8p.

HENRY, C.; MORGAN, D.; WEEKES, R.; DANIELS, R.; BOFFEY, C. Farm scale evaluations of GM crops: monitoring gene flow from GM crops to non-GM equivalent crops in the vicinity (contract reference EPG 1/5/138). Part I: forage maize. [S.1.]: Defra, 2003. 25p. (Final report, 2000/2003).

INTERNATIONAL ORGANIZATION FOR STANDARDIZATION. ISO/IEC 17025: general requirements 
for the competence of testing and calibration laboratories. Geneva: ISO, 2005. 28p.

JAMES, C. Global status of commercialized biotech/GM crops. Ithaca: ISAAA, 2010. 25p. (ISAAA Briefs, 42).

JEMISON, J.M.; VAYDA JUNIOR, M.E. Cross pollination from genetically engineered corn: wind transport and seed source. AgBioForum, v.4, p.87-92, 2001.

LUNA, V.S.; FIGUEROA, M.J.; BALTAZAR, M.B.; GOMEZ, L.R.; TOWNSEND, R.; SCHOPER, J.B. Maize pollen longevity and distance isolation requirements for effective pollen control. Crop Science, v.41, p.1.551-1.557, 2001.

MA, B.L.; SUBEDI, K.D.; REID, L.M. Extent of cross-fertilization in maize by pollen from neighboring transgenic hybrids. Crop Science, v.44, p.1.273-1.282, 2004.

RAMALHO, M.A.P.; SILVA, N.O. Fluxo gênico em plantas. In: MIR, L. (Org.). Genômica. São Paulo: Atheneu, 2004. p.863-884.

SIGMA PLOT. Scientific graphing software. Version 10.0. San Rafael: Jandel Corporation, 2006.

Recebido em 10 de junho de 2011 e aprovado em 28 de maio de 2012 